\title{
MARRIAGE AND THE INDEPENDENCY OF WOMEN (A CASE STUDY ON EARLY MARRIAGE IN LOCAL AREA IN MADURA)
}

\author{
Jamilah \\ Dosen Luar Biasa Fakultas Humaniora dan Budaya UIN Malang
}

\begin{abstract}
Abstrak
Perkawinan merupakan suatu ikatan yang mengandung nilai ibadah dan suatu tahap kehidupan penting bagi seseorang dengan berbagai tujuan hidup. Oleh karena itulah,segala aspek yang terkait dengan perkawinan haruslah didasari dengan keputusan yang disadari secara penuh bagi yang melakukan, yaitu suami atau istri. Dalam konteks ini, kadangkala kemandirian dan hak perempuan seperti penentuan usia perkawinan dan pemilihan pasangan terabaikan terutama pada masyarakat desa atau daerah-daerah dimana masih terdapat bias gender terhadap status dan perempuan yang dikonstruk sebagai suatu kearifan dan norma lokal yang seringkali berdampak negatif bagi semua pihak. Dengan demikian, kemandirian perempuan dalam perkawinan semestinya dikembalikan pada pada perempuan agar tujuan mulia perkawinan dapat terwujud
\end{abstract}

\section{A. Preface}

Marriage serves many purposes for either men or women. For women in rural area, for instance, marriage is an important phase of their life. It can be perceived as natural cycle of life by the women. For many, it is also a need to preserve their existences in society. For individuals, marriage is a variously economic ticket, a socializing influence, a form of child care, a means of escape from social constrains and the locus of many other hopes and desires. What is interesting from the point of viewing marriage is the different purposes which marriage is expected to serve women in various angles. In local area, usually the emphasis on 
marriage for women has been on moral and social as well as, to some extent, outcomes, both for themselves and for society. As the irony of the fact of the importance of marriage, particular aspect in marriage such as age is mostly ignored by society and by women themselves although it is closely related to the issue of women's independency. The line of the debate is on the prerogative of women in deciding the age that they want to get married and the person they want to marry with. However, not all the cases of early marriage are the problems of loosing personal prerogative as it can be free and personal choice

\section{B. Early Marriage and the independency of local area women}

As Blackburn ${ }^{1}$ suggested that the age at which it is appropriate for girls to marry has been a contentious matter in many countries. Furthermore, she pointed out that for certain societies, marriage is considered as family's prerogative. It brings up the age of marriage to be quite young. Children in this case are rarely to be consulted about marriage and they seldom propose their own will. Moreover, the marriageable age based on the adulthood qualities for daughters to be a wife and a mother is usually ignored by people in general and particularly by the parents. In fact, if the qualities are put into main consideration the marriage could run stable. Furthermore, divorce and its undesirable impacts are probably can be avoided. Then, the next question is that should girls or daughters are allowed to choose their husbands by themselves. The standard age which is suitable for getting marriage is another main question. The aim of proposing these two inquiries is to let the girls know all

\footnotetext{
${ }^{1}$ Susan Blackburn, women and the State in Modern Indonesia (UK, Cambridge University Press;2004) p. 57
} 
the consequences of marriage. For instance, girls should know the result of getting marriage before eighteen such as how quickly their body will deteriorate after giving a birth.

Consideration of girls to get marriage earlier is differently argued by people. For many, if the girls had menstruated and reached the age of fifteen, she was old enough to marry. A story of Don Juan reveals the way of Minangkabaus people perceive marriageable age for their daughters. This story tells:

It is right for parents to choose the husband. And among us (matrilineal) Minangkabaus, the rights of male elders must be consulted. If you leave it to a girl, she may be tricked into marriage by a womanizer or misled by men who deceived girls as we read about in Europe. ${ }^{2}$

Strictly speaking, early marriage in one village in Madura is commonly practiced and is differently perceived by people in this villagen the one hand, marriage in the very early age may generate undesirable impact on the children particularly on women as wives. Through interview, many possible undesirable impacts are proposed by women in Tlokoh regarding the age of marriage and the prerogative of marriage itself. . ${ }^{3}$ For many (e.g. a woman figure in the village) pointed out that the practice of early marriage is, to some extent, harmful for women. She puts in this way:

I was very young when I got married. Early marriage can destroy daughters' life because when they got marriage they did not have complete understanding

\footnotetext{
${ }^{2}$ Blackburn,.......p. 60

${ }^{3}$ The interview is taken from research conducted in one village in Kokop Sub-district in Madura as part of the writer's master program.
} 
of how to handle the family. Furthermore, the decision of parents to choose husband for their daughters is also harmful for the husband. The chosen husband may have not reach marriageable age that makes him not ready yet to manage the family's matters. Moreover, he is probably not financially ready yet. As a result, the family may face obstacles due to lack of financial and psychological preparation.

In addition, another chance to interview other respondents reveals the same line of thought to perceive that early marriage is common but less desirable for the wife. For instance, a primary school teacher in this village suggested that to get marriage in the very early age distort girls' freedom to express what they want including their own plan of the future. The independency of daughters to make decision for her personal matters is not on her hands. This is commonly parents' worry that plays role in supporting early marriage to exist in rural area.

Parents are worried if their daughters will not have husband or will get older without any spouses. People in village are economically weak, so they cannot afford school fee to send their children to school. Consequently, most girls have nothing to do. They have no significant activities except helping their parents in the farm or cutting grass for the husbandry. Then, if there is a man asking for marrying the daughters, the parents will agree directly. The opportunity that comes to the village girls in that situation above is getting marriage in the very early of their ages. Sometimes they do not know what the meaning of being a wife is. The worst thing is that the parents just accept the husband's offering 
without asking their daughters before whether they like to marry soon or not. ${ }^{4}$ This due to a social rights for parents as the guardians for their children particularly daughters.

Interestingly, as suggested by another research ${ }^{5}$ in Madura which reveals the fact of minimum age of marriage that is still low. This research explains the way of Madurese views on marriage that for them the important thing is to follow their own version of Islamic law. In addition, anecdotal evident is also found in this research about special dispensation of marriage age. Some parents usually collude with some local officials in disguising child marriage. This "negotiation" usually occurred due to the marriage below the age of sixteen are not permitted officially. As a result, corruption of age is issued or age can be incorrectly recorded at marriage. In addition, the corruption may be urgently to be practiced due to certain circumstances such as pregnant girls who need to be married off quickly. However, cultural attitudes are also important: particularly in strong Islamic rural areas many people consider it desirable that girls be married as early as possible. ${ }^{6}$ It is commonly found that Indonesians practice cultural belief and make the practice as legal that is often justified by religion. A notion proposed by Mulia in her article "Toward Just Marital Law" argues that

\footnotetext{
${ }^{4}$ The idea is concluded from the result of interview with the wife of social and religious figure of the village where the research is conducted. Her husband's social position makes her to be respected by the people. She also play significant social role to be consulted when there is a social problem. However, her role becomes significant after the death of her husband. She was around 12 years of her age when she got married. The phenomena of women loosing independency in aspect of marriage is a cross cultural phenomenon and long rooted tradition. History of Pagan Community also notes that women were regarded as only sexual object of men. Sometimes, the fathers of Pagan girls just gave their daughter to men without asking anything or the father just asking other fathers to be allowed to marry their daughter. It happened as if an exchange daughters to be wives.

${ }^{5}$ See research conducted by Jones (2001) in Blackburn

${ }^{6}$ For further explanation on the practice of early marriage see BlackBurn, Women... chapter 3.
} 
Indonesian society is currently facing a number of social problems related mostly on the issue of women. Particular cases related to women such as exploitation and discrimination exist in Indonesian society, including domestic violence, women and children trafficking through marriage, high number of underage children marriage and unregistered marriage, and widespread practice of prostitution need a reform of Marital Law although those aforementioned problems are social problems. ${ }^{7}$

Additionally, the previous research in Bangkalan regency of Madura in 1977 suggested the ineffectiveness of the 1974 Marriage Law in this island which is also responsible for the age of marriage. Marriage in the earlier age was remained widespread among girls below twenty in one of sub-districts in Bangkalan regency. There was an identifiable trend toward early marriage. This research also reveals that the marriage of girls under sixteen remained commonplace and was widely accepted within the community. ${ }^{8}$

Like in this village where the research is conducted, early marriage among teenagers is a widely accepted to be practiced. The teenagers, especially women, who have graduated from elementary school (SD) are considered or might consider themselves as capable to get married. The previous observation confirmed the earlier evident that a far greater percentage of girls marry before twenty. Most of people in this village marry on the age of 13-16 years old for the women. Meanwhile, the men usually aged 16 or 17 years old when they get married. During this research is conducted, there is a young couple is found to have the

\footnotetext{
${ }^{7}$ Musdah Mulia, Toward Just Marital Law, issued (dialog con I'Islam) at WWW.cisro.net/index.php

${ }^{8}$ BlackBurn, Women........ P. 78
} 
formal letter from KUA while they got married when the woman was 15 and the man was 17. Therefore, it is not surprising when people in those ages are already become a widow or widower.

Nonetheless, it is also a possibility that among the people in the village there are still who practice later marriage. Their proportion, however, still less than those who marry earlier due to the social tradition of the village. Moreover, in local madrasah particular classical Islamic books such as uqudul Lujen and Risalah Nikah are already taught for the teenagers. ${ }^{9}$

Much has been argued about the tradition of early marriage in this village, including the women themselves. Other women saw marriage in the very early as a significant impact which is needed to be brought into line with its search for the benefits and social order. ${ }^{10}$ There were a number of reasons for this acceptance. According to those who agree with the tradition of early marriage, it is good for women socially and economically. It seems that this village women view that early marriage can be tolerated due to its positive aspects that can prevent youngsters from undesirable impacts of free relationship, free sex and uncontrolled social interaction. By choosing husband for the daughters, parents are released from the responsibility to protect the daughters from bad things. Moreover, this is also for those girls who have no particular activities such as working or studying. From the idea releasing

\footnotetext{
${ }^{9}$ The content of those two classical Islamic text books are about all aspects of marriage such as right and duties of wife and husband. Usually they are also taught in another Islamic educational institution like in pesantren.

${ }^{10}$ From the total number of respondents (45 women) only two people who pointed out the undesirable impact of early marriage. Meanwhile, the rest of respondent view the marriage earlier positively. However, those two women still accepted to get marry earlier although they propose the less desirable aspect of the practice.
} 
responsibility, women or daughters tend to be a burden for parents in terms of culture, local norms and religious doctrines. The emphasis of protection is much on women including to provide a husband for the girl since the boys do not get the same treatment.

Social order is another point to let the children marry earlier. What is meant by social order is social construction what activity is less accepted in this village. It is considered a taboo if single women walk around the village without any clear needs. This phenomenon of social construction leads to the idea of the separation of public and private sphere becomes crucial to control women's sexuality. Therefore, sexual morality is the concern to "protect" women from "being alone" in public sphere but not protecting men. In most women's view, it is better if women with no exact activities get married earlier in Madura particularly in rural area. It will be social problems if they find single women do such activities. People, men and women, will make it as a social issue that will probably make them discuss the girls' attitude to their parents or their relatives. Therefore, social control towards women is reflecting the issue of women status and role socially and culturally that may be different across culture and religion. Take for example what has been proposed by Whyte ${ }^{11}$ that women's status and their role in rural Asia still experienced the traditional sex role concept in the nuclear family. Meaning that, they still perform four common roles such as a wife, a housekeeper, childrearer and as a mother. In addition, a society that has been gendered, he stated that "women and men, girls and boys, are treated in systematically different ways (by both women and

\footnotetext{
${ }^{11}$ Robert Whyte Orr and Pauline Whyte, the Women in Rural Asia (USA,Westview Press, Inc; 1982)
} 
men). They have different experiences at school, at work and at home, they do different things and different things are expected of them. In other words, women and men have different life experiences to an extent that cannot be explained by simple biological differences between the sexes."

Then, it is interesting to consider how people in local area like in this village interpret what is considered to "have activity" and "not to have activity". Helping parents in farming or cutting grass for feeding the husbandry are not quite enough to be called as an activity. This is my understanding that "activity" for people in this community is working to be waged or to get money. Therefore, most women try to work to get money to lessen the parents' burden financially even to financially support their families. The girls, usually, earn money from trading or they go to other places such as to Kalimantan and mostly to other parts in east Java. Those activities can be considered as "activity". Other words, women are led to be independent economically. Therefore, when they are not working to get the money, they are perceived to not have the clear activities, then. However, the primary emphasis is not producing much money. It is not all the case that women must be independent. Working is just to make women not to do useless things outsides the house. This is due to people concern much on the social norm of two different sexes' social relationship (men and women) to search the harmony and to maintain the social order. Women are socially protected in this case. 
The logic of practicing early marriage as one good way to maintain social order also explains why parents prefer their daughters marry earlier. Parents are usually happy when a man asks the daughter to be his wife. There are several reasons which may contribute in this case. First, to have son in-law earlier is family's pride. It is a pride for parents when there is an offering for marriage for their daughters. As informed by an informant from local government office in Kokop sub-district that early marriage is part of parents' pride. $^{12}$ His information also reveals the common range for daughters to get marriage. It is around 11 until 12 years old. Parents may feel worried when the daughters have not got married when they aged more than 16. It will be a perception that the daughters are hard to find a husband and it will be a big worry for them.

The most interesting argument and forthright views are expressed by two women in this village (Ainy and hajar). Hajar made a strong argument for women to accept the practice of early marriage and the authority of parents to choose husband for them. In her view, it is essential to marry earlier for women in Madura considering their future live. Women would need to learn to realize that they need a partner in their life because it is inescapable fact that the ideas of women are men's partner in many respects. She pointed out her agreement in this way:

I agree with the tradition of early marriage in Madura particularly in this village. Marriage aims for taking care and protecting women's life in the

\footnotetext{
${ }^{12}$ The informant works in the office of local government in Kokop for most ten years and he is one of senior officer in this rural area. He used to deal with social problems within the society due to his duty as well as his responsibility for social welfare.
} 
future emotionally as well as economically. That is why I support early marriage because it will be safe women's life earlier. When I got married in the very early of my age, I did not dare to refuse the offering of a man because I was afraid that I would have no husband easily in the next time. Although my first marriage ended with divorce but it was not because of my husband's fault or mine. My husband, he was the good choice for me. I prefer to divorce with him because external problems beyond our personal problems. Anyway, early marriage is good to be accepted by women.

The focus here is on the fear of finding a husband not merely finding the right person to be long life partner. This is such kind, to the writer, of personal fear to not have a husband if once a woman refuse an offering of marriage. It will be bad luck for women in the future. In addition, surrounding people will question a woman who refuses a man. They may think that this woman is too selective for woman's standard in rural area. Woman can be struck down by a calamity by this.

In terms of "men's protection" as has been suggested by Hajar, Ainy is another woman who views positively on early marriage. According to this one-child mother, early marriage is not a big thing for Madurese people since women in Madura seldom to have specific activities. To quote Aini's statement “ It is better if women get married and there is husband who will protect them. What these two women said about women and early marriage is basically in line with the thought of most women in the village. From the total number of respondent (45 women from different socio-economical backgrounds) only two of them who 
consider the undesirable impacts of early marriage on women. Meanwhile, the rest tend to give positive response to marry earlier. For them, marry is life cycle that women should pass trough in their life. One aspect of life is to find our soul mate as our partner in life through marriage. If a man comes to propose marriage, there is no reason for woman to refuse as long as he is morally and socially is admitted by people.

A recent case of early marriage occurred in this village of which a twelve-year old girl got married with a boy who is in the same age with her. The parents are curious that their daughter had special relationship with the boy. When the boy made the first visit, the girl's parents ask him to marry the girl. Interestingly, the boy agreed as well as his parents. Then, the marriage occurred by that time. From the girl's family, parents feel that they already done their responsibility to protect their daughter's from immoral attitude and to find a husband for her. When this young wife was interviewed, she reveals the way she thought about her early marriage this way:

I do not know what the meaning of being women is. I just have to follow what my parents order me to do especially about marriage. When I knew a man and he visited my house, my parents proposed us to get married. I accepted it. Then, what I have to now is just to follow my husband wherever he goes.

For such women in this village, early marriage had an almost personally revelatory impact and bonded them to the new experience. And it was marriage earlier that protects them from negative impact of free social interaction with men. It was also early marriage which gives them economical as well as social "protector". A partner in family bound who can be a partner in several affairs. Therefore, for almost women in this village, it is not a big 
issue to be questioned and to against the practice of early marriage as women may experience the positive aspects of it. However, it does not mean that they do not consider the negative aspect that they just find early marriage is one way to protect women socially and economically. It might be argued, then, particular Madurese women give their right to be independent in marriage to those who represent them socially. It is not a big deal for them since gender issues (e.g. subordination) internalize in a local context and it is already accepted.

\section{Conclusion}

Above all the issues, marriage in a local norm, to some extent, ignores women's independency to regulate their marriage in particular aspects. Therefore, a mutual consent of women becomes critical in marriage although women "sincerely" abandoned her rights to be represented by their male guardians (walis) in marriage. Women should be ensured their freedom in such situations on the concept of consultation as the basic principle of marriage since women must be acknowledged their personal and basic rights to be independent to make decision in their life. In closing it may be safely argued that marriage is a media of which gender is respected and equal rights (men and women) are admitted by social and religious framework. As all such attempts to describe the independency of women in relation with marriage, further research should be conducted. 


\section{REFERENCES}

Blackburn, Susan, women and the State in Modern Indonesia,UK: Cambridge University Press, 2004

Bowen, John R, Islam, Law and Equality in Indonesia, Cambridge: Cambridge University Press, 2003

BPS Bangkalan,Bangkalan in Figures 2003, Bangkalan: BPS kabupaten Bangkalan, 2004

Ellington, Stephen and M. Christian Green, Religion and Sexuality in Cross Cultural Perspectives, New York: Routhledge, 2002

Faisal, Sanapiah, Format-Format Penelitian Sosial, Jakarta: PT Raja Grafindo Persada, 2001

Mayling, Oey, et all., Indonesian Women, The Journey Continues, Canberra: Goanna Print Pby Ltd., 2000

Mulia, Musdah, Toward Marital Law, http/ WWW.Centro.Com

Mulyati, Sri (ed), Relasi Suami Istri Dalam Islam, Jakarta: PSW UIN Jakarta, 2004

Orr, Robert Whyte and Pauline Whyte, the Women in Rural Asia, USA: Westview Press, Inc, 1982

Report of Proceeding on The Regional Workshop, Islam, Reproductive Health and Women's Rights, organized by Sisters in Islam, held in Kuala Lumpur Malaysia at $20^{\text {th }}-23^{\text {rd }}$, August, 1998

Subaharianto, Andang, et all., Tantangan Industrialisasi Madura, Malang: Bayumedia Publishing, 2004 